\title{
Lupus nephritis class I accompanied by tubulointerstitial nephritis with marked T-lymphocyte infiltration in an HTLV-1 positive patient
}

\author{
Toshiyuki Imasawa $\cdot$ Hiroshi Kitamura $\cdot$ Motonobu Nishimura \\ Takehiko Kawaguchi $\cdot$ Katsuyoshi Takata Tadashi Yoshino • \\ Yuichi Sugisaki
}

Received: 27 April 2012/Accepted: 17 October 2012/Published online: 3 November 2012

(C) Japanese Society of Nephrology 2012

\begin{abstract}
We herein describe the case of a 40-year-old Japanese male who was admitted to our hospital because of a continuous remittent fever lasting 1 month. He fulfilled the items of the classification criteria for the diagnosis of systemic lupus erythematosus (SLE). The administration of $20 \mathrm{mg}$ per day of oral prednisolone completely diminished his clinical symptoms. However, his renal biopsy performed 1 day after the admission showed marked pathognomonic characteristics. Not only did his glomeruli show class I lupus nephritis with mesangial depositions of $\mathrm{IgG}$, IgA, C3, and C1q, but also tubulointerstitial nephritis with marked T-lymphocyte infiltration. These infiltrated T cells partly had nuclear atypia. The patient was positive for human T cell leukemia virus type 1 (HTLV-1) antibodies. Furthermore, clonal rearrangements of $\mathrm{T}$ cell receptorgamma chain gene was detected in the DNA extracted from his kidney sections by the polymerase chain reaction (PCR) method. A second renal biopsy 6 months after the prednisolone treatment showed that the infiltrating $\mathrm{T}$ lymphocytes had markedly diminished. This is the first case report
\end{abstract}

T. Imasawa $(\bowtie) \cdot$ M. Nishimura $\cdot$ T. Kawaguchi Department of Internal Medicine, National Hospital Organization Chiba-East Hospital, 673 Nitona-cho, Chuoh-ku, Chiba, Chiba 260-8712, Japan

e-mail: imasawa@cehpnet.com

T. Imasawa $\cdot$ H. Kitamura

Department of Renal Pathology, National Hospital Organization Chiba-East Hospital, Chiba, Japan

K. Takata $\cdot$ T. Yoshino

Department of Pathology, Okayama University School

of Medicine, Okayama, Japan

Y. Sugisaki

Department of Pathology, Nippon Medical School, Tokyo, Japan of lupus nephritis class I with tubulointerstitial nephritis, which might include oncogenic $\mathrm{T}$ lymphocytes, in an HTLV-1 positive patient.

Keywords Systemic lupus erythematosus - Human T cell leukemia virus type $1 \cdot \mathrm{T}$ lymphocytes $\cdot$ Lupus nephritis

\section{Introduction}

Human T cell leukemia virus type 1 (HTLV-1) is a member of a group of mammalian C-type retroviruses and is endemic in southern Japan, the Caribbean, and parts of South America, Africa, and the Middle East [1]. It is well known that HTLV-1 causes adult T cell lymphoma (ATL) $[2,3]$ and HTLV-1 associated myelopathy (HAM)/tropical spastic paraparesis (TSP) [4, 5]. Interestingly, it was shown that the transgenic expression of HTLV-1 in mice was associated with autoimmunity [10]. In humans, HTLV-1 infection has also been hypothesized to play an important role in the pathogenesis of various autoimmune diseases, such as Sjögren's syndrome and rheumatoid arthritis [6-9]. In particular, an association between systemic lupus erythematosus (SLE) and C-type retrovirus has been suspected not only in humans [11-14] but also in mice [15, 16]. The mechanism underlying how HTLV-1 causes SLE remains elusive, but the postulated roles for such retroviruses in the etiopathogenesis of SLE are considered to include intrinsic effects, mimicry of antigens, and/or effects as stimulators of autoimmunity $[17,18]$. In fact, there have been previous case reports of patients with SLE and ATL [19, 20], SLE and HAM [21, 22], and SLE and the persistent carrier state of HTLV-1 infection [23]. We herein report the first case in which a kidney biopsy revealed lupus nephritis with interstitial nephritis that might partly include oncogenic $\mathrm{T}$ 
lymphocytes in an HTLV-1 positive patient. This case again suggests the involvement of HTLV-1 infection in the pathogenesis of SLE.

\section{Case report}

The patient was a 40-year-old Japanese male who was admitted to our hospital because of a remittent fever, which lasted for approximately 1 month. The patient was born in Osaka prefecture and then moved to Chiba prefecture in Japan. These areas do not have endemic HTLV-1. No abnormalities had ever been detected in the patient's annual examinations, and his past history was noncontributory. Before admission to our hospital, he continuously received cefazolin intravenously for 7 days at another hospital, but his remittent fever continued. At that time, the patient had specific abnormalities in his laboratory data, such as antinuclear antibody (ANA) positivity, double-strand DNA antibody (dsDNA $\mathrm{Ab}$ ) positivity, and decreasing complement hemolytic activity. At that point, the patient was referred and admitted to our hospital. At admission, he was severely debilitated because of a sustained loss of appetite. The physical examination showed: height $175.6 \mathrm{~cm}$; body weight $82.0 \mathrm{~kg}$ (BMI 26.6), which was $8 \mathrm{~kg}$ less than 1 month before; blood pressure $97 / 61 \mathrm{mmHg}$; and $\mathrm{SpO}_{2}$ $98 \%$, with a regular heart rate of $76 / \mathrm{min}$. No crackles or murmurs were detected on chest auscultation. The patient's abdomen was normal. Costovertebral angle tenderness was not detected. There was a tattoo, which he had received at age 20, on his back. There were no other abnormalities on his skin. A neurological examination did not reveal any abnormalities. No superficial lymph node swelling was detectable. Ophthalmological abnormalities were also not detected.

Table 1 Laboratory tests on admission

\begin{tabular}{|c|c|c|c|c|c|}
\hline Urinalysis & & Blood chemistry & & Immunology & \\
\hline Gravity & 1.007 & $\mathrm{TP}$ & $5.7 \mathrm{~g} / \mathrm{dl}$ & CRP & $2.94 \mathrm{mg} / \mathrm{dl}$ \\
\hline $\mathrm{pH}$ & 7 & Albumin & $2.5 \mathrm{~g} / \mathrm{dl}$ & HBs-Ag & $(-)$ \\
\hline $\mathrm{RBC}$ & $0-1 / \mathrm{HPF}$ & AST & $186 \mathrm{IU} / 1$ & $\mathrm{HCV}-\mathrm{Ab}$ & $(-)$ \\
\hline WBC & $0-1 / \mathrm{HPF}$ & ALT & $106 \mathrm{IU} / 1$ & $\mathrm{HIV}-\mathrm{Ab}$ & $(-)$ \\
\hline Protein & $0.52 \mathrm{~g} / \mathrm{gCre}$ & $\mathrm{LDH}$ & $797 \mathrm{IU} / 1$ & ASO & $67 \mathrm{IU} / \mathrm{ml}$ \\
\hline NAG & $13.9 \mathrm{U} / 1$ & ALP & $266 \mathrm{IU} / 1$ & $\mathrm{RF}$ & $(-)$ \\
\hline$\beta 2-\mathrm{MG}$ & $1172 \mu \mathrm{g} / 1$ & Tbil & $0.3 \mathrm{mg} / \mathrm{dl}$ & Anti-nuclear-Ab & $1: 80$ \\
\hline \multirow[t]{2}{*}{ BJP } & $(-)$ & $\mathrm{Na}$ & $128 \mathrm{mEq} / \mathrm{l}$ & Anti dsDNA & $53 \mathrm{IU} / \mathrm{ml}$ \\
\hline & & $\mathrm{K}$ & $3.9 \mathrm{mEq} / 1$ & Anti SS-A & $83.5 \mathrm{U} / \mathrm{ml}$ \\
\hline Blood cell count & & $\mathrm{Cl}$ & $93 \mathrm{mEq} / 1$ & Anti SS-B & $<7.0 \mathrm{U} / \mathrm{ml}$ \\
\hline WBC & $3300 / \mu 1$ & BUN & $10.5 \mathrm{mg} / \mathrm{dl}$ & $\mathrm{CH} 50$ & $19 \mathrm{U} / \mathrm{ml}$ \\
\hline Stab & $2 \%$ & Cre & $1.0 \mathrm{mg} / \mathrm{dl}$ & $\mathrm{C} 3$ & $34.8 \mathrm{mg} / \mathrm{dl}$ \\
\hline Seg & $84 \%$ & UA & $4.1 \mathrm{mg} / \mathrm{dl}$ & $\mathrm{C} 4$ & $15.5 \mathrm{mg} / \mathrm{dl}$ \\
\hline Lymphocyte & $7 \%$ & $\mathrm{Ca}$ & $7.8 \mathrm{mg} / \mathrm{dl}$ & IgG & $1410 \mathrm{mg} / \mathrm{dl}$ \\
\hline Mono & $4 \%$ & $P$ & $3.0 \mathrm{mg} / \mathrm{dl}$ & IgG1 & $54.5 \%$ \\
\hline Eosino & $3 \%$ & Tcho & 146 mg/dl & $\operatorname{IgG} 2$ & $40.6 \%$ \\
\hline $\mathrm{RBC}$ & $4.55 \times 10^{6} / \mu 1$ & BS & $93 \mathrm{mg} / \mathrm{dl}$ & IgG3 & $3.2 \%$ \\
\hline Hemoglobin & $12.6 \mathrm{~g} / \mathrm{dl}$ & HbA1c (NGSP) & $6.9 \%$ & IgG4 & $1.7 \%$ \\
\hline Hematocrit & $36.5 \%$ & & & IgA & $221 \mathrm{mg} / \mathrm{dl}$ \\
\hline $\mathrm{MCV}$ & $80 \mathrm{fl}$ & & & $\operatorname{IgM}$ & $90 \mathrm{mg} / \mathrm{dl}$ \\
\hline Platelet & $16.5 \times 10^{4} / \mu \mathrm{L}$ & & & $\operatorname{IgE}$ & $83.5 \mathrm{IU} / \mathrm{ml}$ \\
\hline \multirow[t]{2}{*}{ Reticulocyte } & $0.3 \%$ & & & sIR-2R & $2770 \mathrm{U} / \mathrm{ml}$ \\
\hline & & & & $\mathrm{M}$ protein & $(-)$ \\
\hline
\end{tabular}

To convert $\mathrm{Hb}$, TP, and Albumin in $\mathrm{g} / \mathrm{dl}$ to $\mathrm{g} / \mathrm{l}$, multiply by 10 ; Tbil in $\mathrm{mg} / \mathrm{dl}$ to $\mu \mathrm{mol} / \mathrm{l}$, multiply by 17.1 ; BUN in $\mathrm{mg} / \mathrm{dl}$ to $\mathrm{mmol} / \mathrm{l}$, multiply by 0.357 ; $\mathrm{Cr}$ in $\mathrm{mg} / \mathrm{dl}$ to $\mu \mathrm{mol} / \mathrm{l}$, multiply by 88.4 ; UA in $\mathrm{mg} / \mathrm{dl}$ to $\mu \mathrm{mol} / \mathrm{l}$, multiply by 59.48 ; Ca in $\mathrm{mg} / \mathrm{dl}$ to mmol/l, multiply by 0.2945 ; Tcho in $\mathrm{mg} / \mathrm{dl}$ to mmol/l, multiply by 0.02586 ; C3, C4, IgG, IgA, and IgM in $\mathrm{mg} / \mathrm{dl}$ to g/l, multiply by 0.01

$R B C$ red blood cells, $H P F$ high-power field, $W B C$ white blood cells, $N A G N$-acetylglutamate, $M G$ microglobulin, Stab stab cell, Seg segmented neutrophils, Mono monocytes, Eosino eosinophilic cells, $M C V$ mean corpuscular volume, $T P$ total protein, AST aspartate aminotransferase, ALT alanine aminotransferase, $L D H$ lactate dehydrogenase, $A L P$ alkaline phosphatase, $T b i l$ total bilirubin, $B U N$ blood urea nitrogen, $C r$ creatinine, $U A$ uric acid, Tcho total cholesterol, BS blood sugar, HbAlc hemoglobin A1c, CRP C-reactive protein, ASO antistreptolysin-O, C3 complement $3, I g G$ immunoglobulin $\mathrm{G}, R F$ rheumatoid factor, $A N A$ antinuclear antibody, $H B s$ hepatitis $\mathrm{B}$ surface, $H C V$ hepatitis $\mathrm{C}$ virus, $M$ protein monoclonal protein 
Table 2 The changes in the clinical data

\begin{tabular}{|c|c|c|c|c|c|c|c|c|c|}
\hline & Normal range & Day 1 & Day 9 & Day 51 & Day 71 & Day 99 & Day 135 & Day 176 & Day 197 \\
\hline Proteinuria (g/gCre) & $<0.15$ & 0.52 & 0.14 & 0.1 & 0.07 & 0.06 & 0.05 & 0.07 & 0.06 \\
\hline NAG (U/l) & $<7$ & 13.1 & 3.3 & nd & nd & nd & nd & nd & 1.8 \\
\hline$\beta 2-\mathrm{MG}(\mu \mathrm{g} / \mathrm{l})$ & $<230$ & 1172 & 2215 & nd & nd & nd & nd & nd & 640 \\
\hline $\mathrm{WBC}(/ \mu \mathrm{l})$ & $3500-9200$ & 3300 & 9000 & 10800 & 11300 & 7800 & 10100 & 8200 & 8900 \\
\hline Lymphocytes (\%) & $30-45$ & 7.0 & 8.7 & 9.8 & 21.0 & 23.0 & 13.0 & 16.0 & 13.5 \\
\hline eGFR (ml/min) & & 67.3 & 85.9 & 102.6 & 101.0 & 94.3 & 92.9 & 91.5 & 90.2 \\
\hline Albumin (serum) $(\mathrm{g} / \mathrm{dl})$ & $3.8-5.3$ & 2.5 & 2.8 & 3.8 & 3.5 & 3.6 & 3.6 & 3.7 & 3.5 \\
\hline AST (IU/l) & $13-33$ & 186 & 19 & 20 & 35 & 40 & 38 & 28 & 22 \\
\hline CH50 (U/ml) & $30-50$ & 19 & nd & 41.1 & 37.4 & 38.8 & 39.7 & 38.3 & 38.3 \\
\hline Anti-dsDNA Ab (IU/ml) & $<20$ & 53 & nd & 192 & nd & 123 & nd & 122 & 104 \\
\hline Anti-nuclear Ab (titer) & $<1: 40$ & $1: 80$ & nd & $1: 80$ & nd & $1: 80$ & nd & $1: 80$ & $1: 160$ \\
\hline sIL-2R (U/ml) & $145-519$ & 2770 & nd & 746 & nd & 817 & nd & 623 & 657 \\
\hline Major axis of the left kidney (mm) & & 137.3 & nd & nd & nd & nd & nd & nd & 121.6 \\
\hline Major axis of the right kidney $(\mathrm{mm})$ & & 134.8 & nd & nd & nd & nd & nd & nd & 127.6 \\
\hline
\end{tabular}

Kidney sizes were measured by ultrasonography

The results of the laboratory tests on admission are summarized in Table 1. No atypical cells were observed in the patient's peripheral blood. He fulfilled four items of classification criteria for the diagnosis of SLE, i.e. lymphocytopenia $(231 / \mu \mathrm{l})$, proteinuria $(0.52 \mathrm{~g} / \mathrm{gCre})$, ANA positivity, and dsDNA Abs. Thus, he was diagnosed to have SLE. We started the patient on $20 \mathrm{mg}$ of oral prednisolone on the day of the admission. As a result, he never experienced the fever again and recovered his appetite promptly. His elevated ALT and AST also started to decrease soon after starting this treatment (Table 2). His condition continued to improve, and he was discharged from our hospital 8 days after the admission.

However, we thought that lymphoproliferative disease could not be ruled out completely. The patient's serum

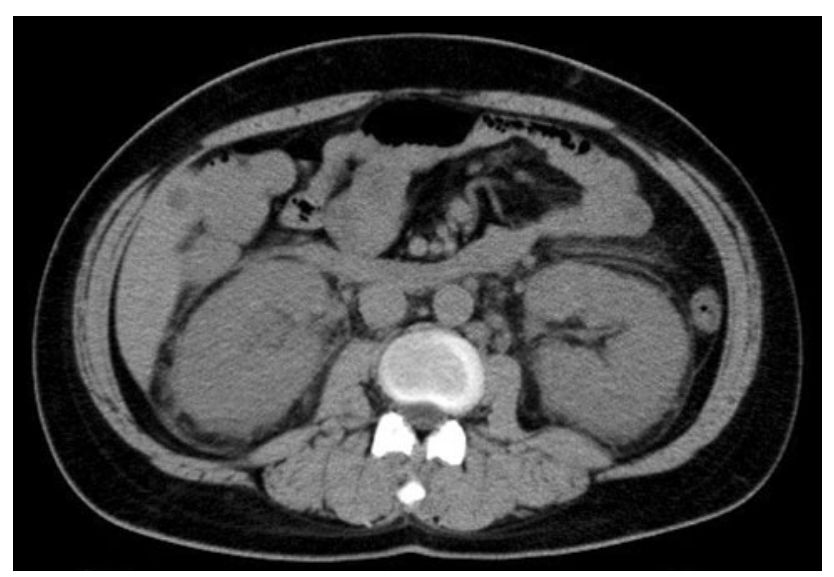

Fig. 1 A CT scan image taken on admission. The abdominal paraaortic lymph nodes were swollen (approximately $1 \mathrm{~cm}$ in diameter). Enlarged kidneys were also observed level of soluble IL-2 receptor was elevated (Table 1). Furthermore, a computed tomography (CT) scan revealed abdominal para-aortic lymph node swelling (approximately $1 \mathrm{~cm}$ in diameter) (Fig. 1). The CT scan also revealed swelling of bilateral kidneys, suggesting infiltration or accumulation of something in the kidney. Therefore, we performed a kidney biopsy to define the etiology of the proteinuria and to determine the cause of the swelling of the kidney 1 day after the admission (day 2).

First renal biopsy

We could observe 20 glomeruli. All glomeruli appeared normal upon examination by light microscopy (Fig. 2a). On the other hand, immunofluorescent staining revealed that $\operatorname{IgG}, \operatorname{IgA}, \mathrm{C} 3$, and $\mathrm{C} 1 \mathrm{q}$, but not $\operatorname{IgM}$, were positive in the mesangial area (Fig. 2c-f). These pathological findings in glomeruli were compatible with class I lupus nephritis [24]. However, it should be noted that the interstitium had marked changes. Approximately $30 \%$ of the area of the interstitium had been occupied by infiltrating small to medium sized lymphoid cells partly with nuclear atypia (Fig. 3a, b). We also detected tubulitis with breaks of the tubular basement membrane. Most populations of the infiltrated cells were positive for CD3 (Fig. 3c), a part of which had enlarged or notched nuclei (Fig. 3d). On the other hand, there were minor populations of CD20-positive cells (Fig. 3e). In addition, these cells were positive for CD4, CD5, and CD8, and negative for CD10, CD21, CD56, MPO, and LMP-1. The Ki-67 labeling index was $49.1 \%$ (Fig. 3f). These findings might suggest the oncogenic proliferation of $\mathrm{T}$ lymphocytes in the interstitium in the kidney. 
Fig. 2 Representative photos from the first kidney biopsy (1). a No apparent abnormalities were detected in any of the glomeruli. This glomerulus was slightly enlarged (major axis; $252 \mu \mathrm{m})$ possibly because of obesity (periodic acid-Schiff stain). b IgG stain. c IgA stain. d IgM stain. e C3 stain. f C1q stain $(\mathbf{a}-\mathbf{f} \times 200)$
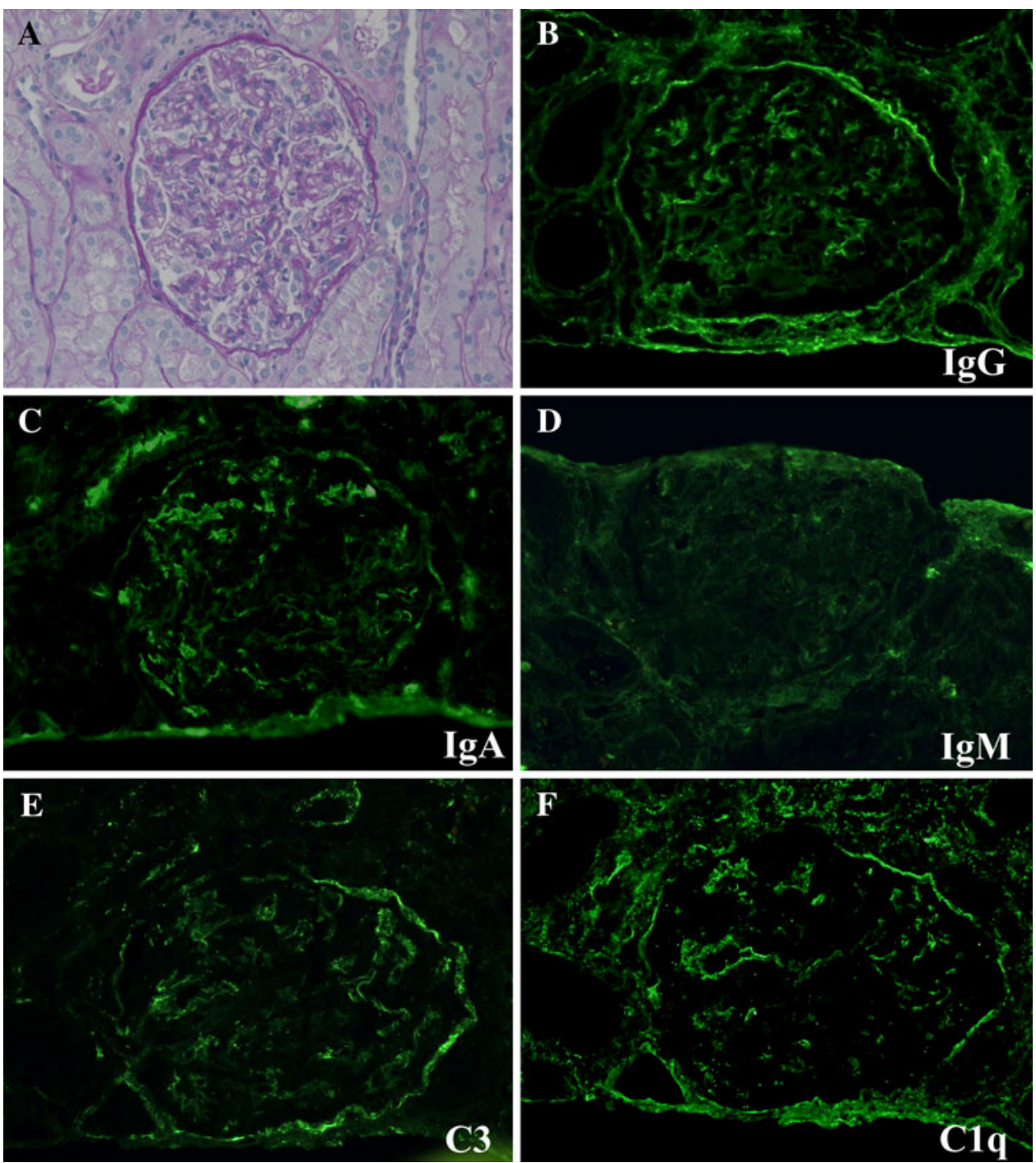

\section{Analysis for HTLV-1}

The finding of infiltrating $\mathrm{T}$ lymphocytes in the interstitium in the first biopsy prompted us to screen the patient for HTLV-1 infection. The chemical luminescence enzyme immunoassay (CLEIA) for serum showed positive results for the HTLV-1 antibody. On the other hand, integration of the HTLV-1 provirus genome was not detected in the DNA of peripheral blood cells by a Southern blot analysis 2 months after the admission to our hospital. Furthermore, we also checked the integration of the HTLV-1 provirus genome in the biopsied frozen kidney tissues by a Southern blot analysis. However, the sample volume was not large enough to obtain DNA for the analysis. Therefore, we performed polymerase chain reaction (PCR)-based clonality assessment according to the method reported previously [25] to investigate whether there were clonal rearrangements of the T cell receptor $\gamma$ (TCR $\gamma$ ) chain gene by using paraffin-embedded kidney sections. As a consequence, apparent clonal bands of $\mathrm{TCR} \gamma$ rearrangement were detected (Fig. 4). The patient's mother was negative for HTLV-1 antibody in the serum.

\section{Follow-up and second renal biopsy}

After the discharge, the patient's condition remained good, without any symptoms. His prednisolone treatment was decreased to $15 \mathrm{mg}$ a day after 3 months. The changes in laboratory data after 3 months are summarized in Table 2 . While the CH50 values were within the normal range, the dsDNA levels were still high. The proteinuria had disappeared. In the abdominal CT scans, the para-aortic lymphadenopathy had markedly diminished 1 month after the treatment (data not shown). The kidney size was slightly decreased compared with that at the first biopsy (major axis of the left kidney: 121.6 vs. $137.3 \mathrm{~mm}$, major axis of the right kidney: 127.6 vs. $134.8 \mathrm{~mm}$ ). Because the specific pathological manifestation of this patient was observed in 
Fig. 3 Representative photos from the first kidney biopsy (2). a Inflammatory cells were spread throughout approximately $30 \%$ of the area of the interstitium (H\&E stain). b The nuclei of some infiltrating cells were enlarged with notched shapes (arrows) (H\&E stain). c Most of the infiltrating cells were positive for $\mathrm{CD} 3$. d The CD3-positive cells had notched nuclei. e CD20-positive cells were minor populations in the interstitium. $\mathbf{f}$ These infiltrating cells were also positive for Ki-67 $(\mathbf{a} \times 40$, b $\times 600, \mathbf{c} \times 100, \mathbf{d} \times 600$, e $\times 100, \mathbf{f} \times 100$ )
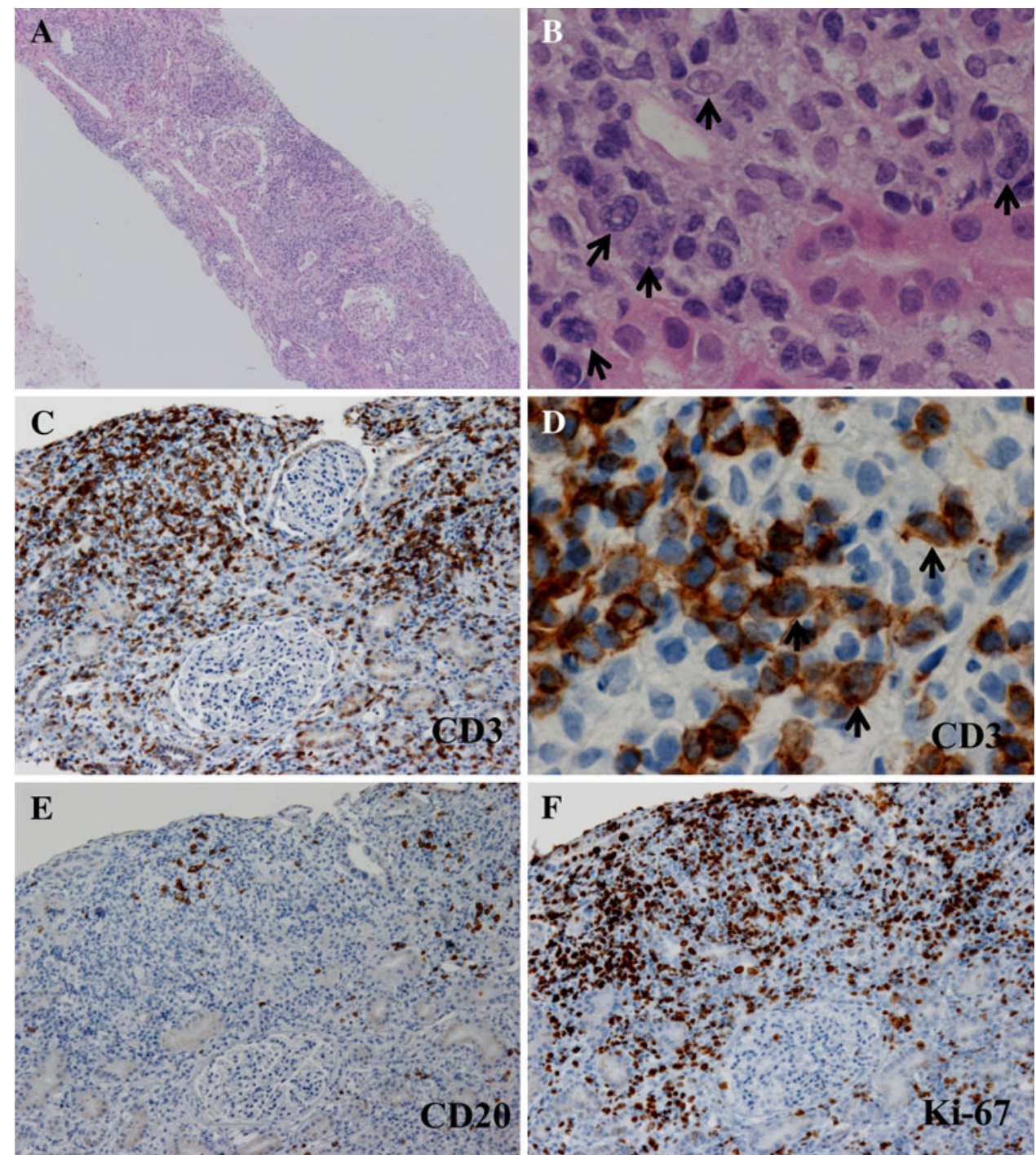

the kidney, a second percutaneous renal biopsy was performed to confirm the efficacy of the treatment 6 months after the first biopsy, and another 20 glomeruli were obtained. All of the glomeruli, except for one collapsed glomerulus, showed an almost normal appearance (Fig. 5a). Furthermore, an immunofluorescent study showed that all deposits had completely disappeared (Fig. 5b-f). In addition, the infiltrating cells in the interstitium were also markedly decreased (Fig. 6a, b).

\section{Discussion}

An association between HTLV-1 and SLE has been discussed for more than 3 decades. Both in humans [12-14, $18]$ and in mice $[15,16]$, the results of previous research have suggested the involvement of C-type retroviruses, including HTLV-1, in the pathogenesis of SLE. While SLE with ATL or HAM is rare in the clinical setting, several reports have described these comorbidities [19-22, 26]. Compared with the previous cases, the most pathognomonic features of this patient are that his renal pathology showed lupus nephritis and marked T-lymphocyte infiltration into the interstitium (Figs. 2, 3) and that these $\mathrm{T}$ cells had abnormal nuclei (Fig. 4). There were no previous reports of such infiltration of $\mathrm{T}$ cells into the renal interstitium in HTLV-1 carriers.

Indeed, tubulointerstitial nephritis may be encountered in lupus nephritis. But, such tubulointerstitial disease is most commonly encountered in class III or IV [27]. Immunofluorescent analysis never showed deposits of immunoglobulin within their tubular basement membranes and interstitium. In addition, $\mathrm{T}$ cells had atypical nuclei and the Ki-67 labeling index was $49.1 \%$. Therefore, we cannot 


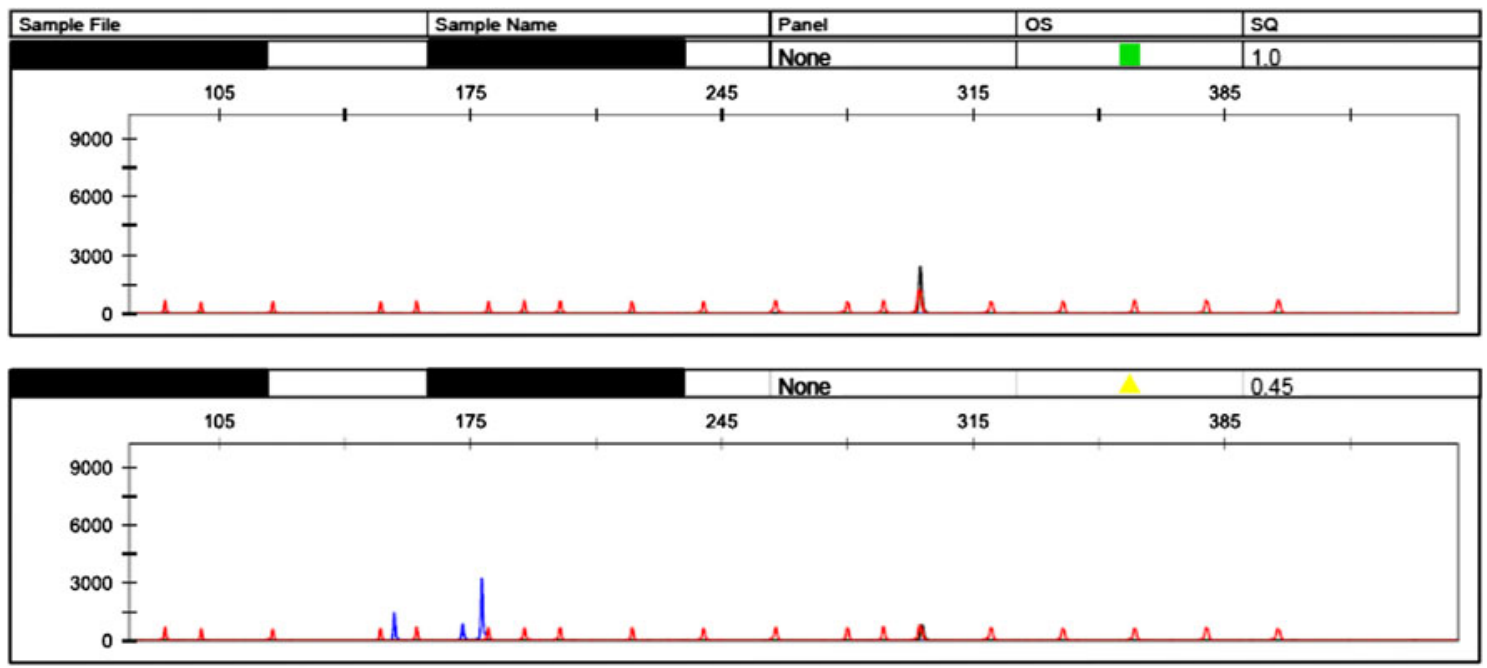

Fig. 4 PCR-based clonality assessment for detecting clonal rearrangements of TCR $\gamma$ chain. The paraffin-embedded kidney section at the first biopsy was used for this analysis to investigate whether there were clonal rearrangements of TCR $\gamma$ chain. Two apparent peaks of clonal bands (blue) from 140 to $180 \mathrm{bp}$ were detected, which indicated that the kidney section should include oncogenic $\mathrm{T}$ lymphocytes. The 300-bp band (black) was an internal positive control

prednisolone per day could completely diminish all clinical symptoms and pathological findings in the kidney. Such effectiveness of $20 \mathrm{mg}$ of prednisolone would be unusual in cases of ATL.

In retrospect, we are not confident that our treatment was the best choice for this patient. The PSL did completely diminish all of his clinical symptoms, and the patient is still stable. In addition, the second renal biopsy revealed that the infiltrating $\mathrm{T}$ lymphocytes had markedly diminished (Fig. 6). Therefore, we decided to continue the same treatment in this situation. However, this treatment would have been insufficient if the patient had been diagnosed with ATL. The patient's AST and ALT, which were elevated on admission, were dramatically decreased by PSL. If a liver biopsy had been performed, it might have shown that oncogenic $\mathrm{T}$ lymphocytes had infiltrated into the liver. In addition, small abdominal paraaortic lymphadenopathies (Fig. 1), which also diminished soon after treatment, might have been caused by oncogenic proliferation of lymphocytes infected by HTLV-1. However, these are now obscure. We will need to take care to rule out the presence of ATL in the future as some reports described that ATL occurred after the treatment of SLE with HTLV-1-positive patients [20, 26].

This is the first case report of lupus nephritis class I with marked interstitial infiltration of $\mathrm{T}$ lymphocytes, which should partly consist of oncogenic ones in an HTLV-1 patient. This case provides evidence further suggesting the involvement of HTLV-1 infection in the pathogenesis of SLE. 

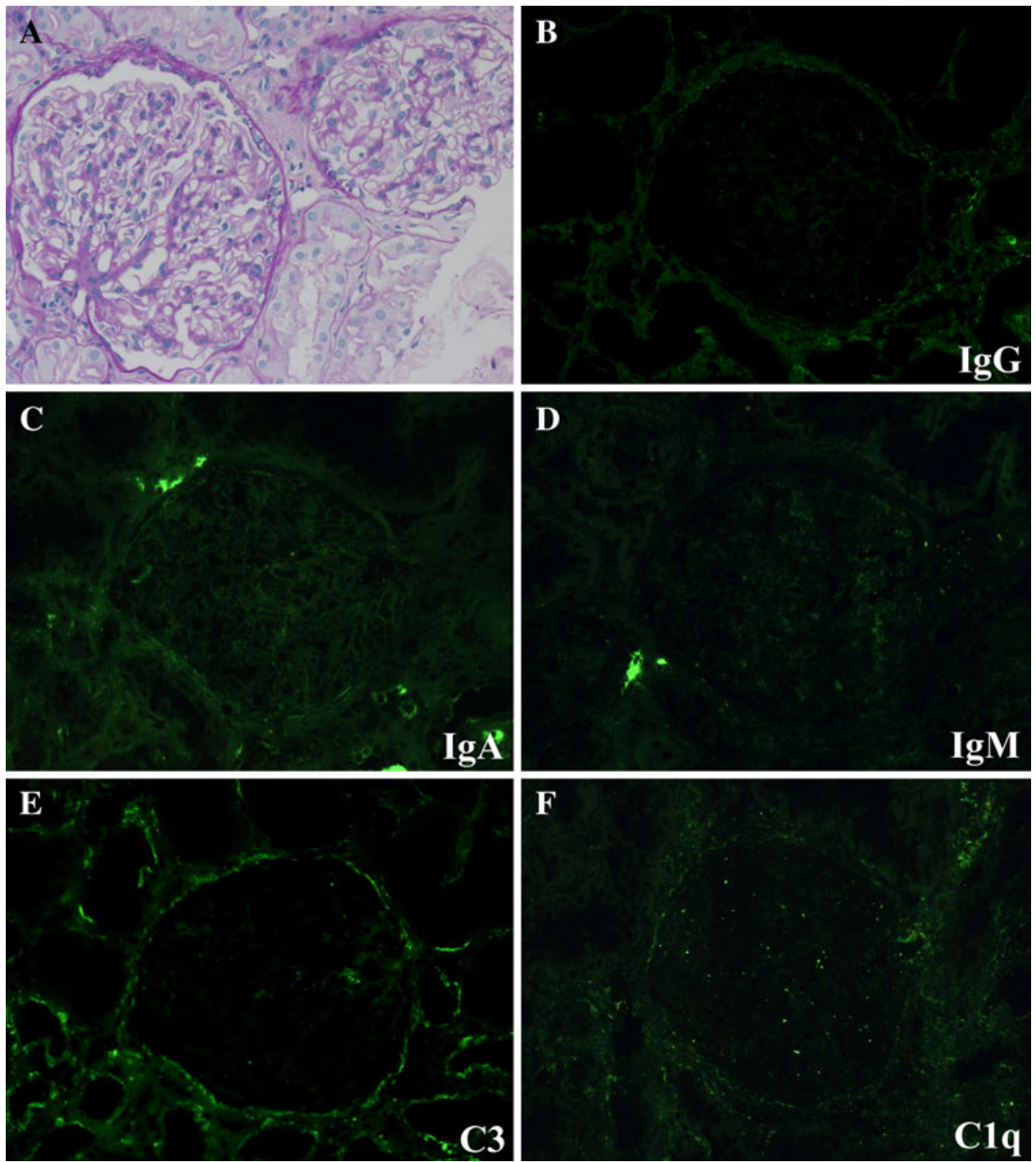

Fig. 5 Representative photos from the second kidney biopsy (1). a No apparent abnormalities were detected in the glomeruli from the second biopsy (periodic acid-Schiff stain). b IgG stain. $\mathbf{c}$ IgA stain. $\mathbf{d}$ IgM stain. e C3 stain. $\mathbf{f}$ C1q stain $(\mathbf{a}-\mathbf{f} \times 200)$

Fig. 6 Representative photos from the second kidney biopsy (2). a Few inflammatory cells were in the interstitium $(\mathrm{H} \& \mathrm{E}$ stain). b Few CD3-positive cells were in the interstitium
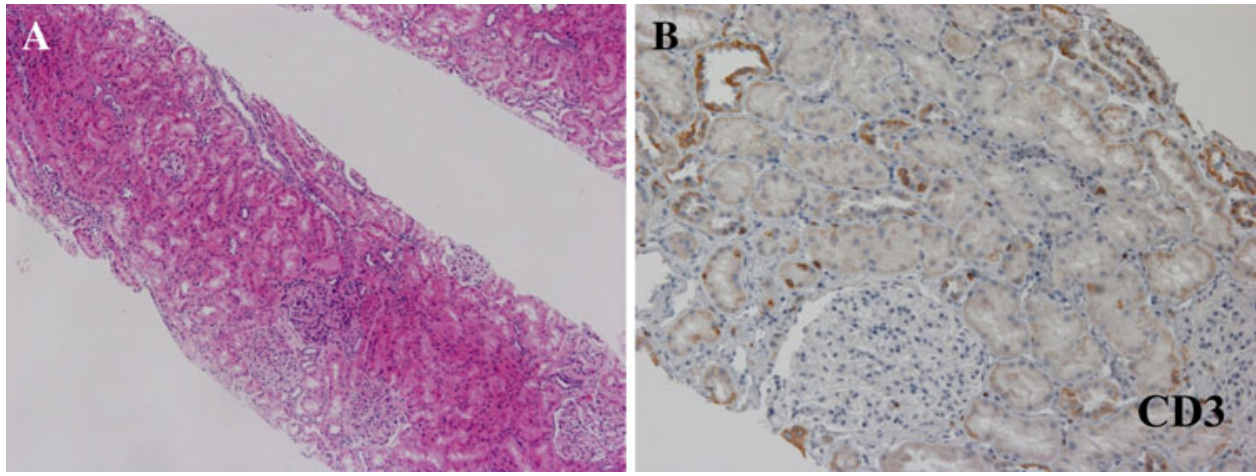


\section{References}

1. Manns A, Hisada M, La Grenade L. Human T-lymphotropic virus type I infection. Lancet. 1999;353:1951-8.

2. Yoshida M, Miyoshi I, Hinuma Y. Isolation and characterization of retrovirus from cell lines of human adult T-cell leukemia and its implication in the disease. Proc Natl Acad Sci USA. 1982; 79:2031-5.

3. Poiesz BJ, Ruscetti FW, Gazdar AF, Bunn PA, Minna JD, Gallo $\mathrm{RC}$. Detection and isolation of type $\mathrm{C}$ retrovirus particles from fresh and cultured lymphocytes of a patient with cutaneous T-cell lymphoma. Proc Natl Acad Sci USA. 1980;77:7415-9.

4. Osame M, Usuku K, Izumo S, Ijichi N, Amitani H, Igata A, et al. HTLV-I associated myelopathy, a new clinical entity. Lancet. 1986;1:1031-2.

5. Gessain A, Barin F, Vernant JC, Gout O, Maurs L, Calender A, de Thé G. Antibodies to human T-lymphotropic virus type-I in patients with tropical spastic paraparesis. Lancet. 1985;2:407-10.

6. Nakamura H, Eguchi K, Nakamura T, Mizokami A, Shirabe S, Kawakami A, et al. High prevalence of Sjögren's syndrome in patients with HTLV-I associated myelopathy. Ann Rheum Dis. 1997;56:167-72.

7. Terada K, Katamine S, Eguchi K, Moriuchi R, Kita M, Shimada $\mathrm{H}$, et al. Prevalence of serum and salivary antibodies to HTLV-1 in Sjögren's syndrome. Lancet. 1994;344:1116-9.

8. Sumida T, Yonaha F, Maeda T, Kita Y, Iwamoto I, Koike T, Yoshida S. Expression of sequences homologous to HTLV-I tax gene in the labial salivary glands of Japanese patients with Sjögren's syndrome. Arthritis Rheum. 1994;37:545-50.

9. Sato K, Maruyama I, Maruyama Y, Kitajima I, Nakajima Y, Higaki $M$, et al. Arthritis in patients infected with human $T$ lymphotropic virus type I. Clinical and immunopathologic features. Arthritis Rheum. 1991;34:714-21.

10. Iwakura Y, Saijo S, Kioka Y, Nakayama-Yamada J, Itagaki K, Tosu M, et al. Autoimmunity induction by human T cell leukemia virus type 1 in transgenic mice that develop chronic inflammatory arthropathy resembling rheumatoid arthritis in humans. J Immunol. 1995;155:1588-98.

11. Strand M, August JT. Type-C RNA virus gene expression in human tissue. J Virol. 1974;14:1584-96.

12. Mellors RC, Mellors JW. Antigen related to mammalian type-C RNA viral p30 proteins is located in renal glomeruli in human systemic lupus erythematosus. Proc Natl Acad Sci USA. 1976;73:233-7.

13. Panem S, Ordóñez NG, Kirstein WH, Katz AI, Spargo BH. C-type virus expression in systemic lupus erythematosus. N Engl J Med. 1976;295:470-5.

14. Imamura M, Phillips PE, Mellors RC. The occurrence and frequency of type $\mathrm{C}$ virus-like particles in placentas from patients with systemic lupus erythematosus and from normal subjects. Am J Pathol. 1976;83:383-94.

15. Izui S, McConahey PJ, Theofilopoulos AN, Dixon FJ. Association of circulating retroviral gp70-anti-gp70 immune complexes with murine systemic lupus erythematosus. J Exp Med. 1979;149:1099-116.

16. Yoshiki T, Mellors RC, Strand M, August JT. The viral envelope glycoprotein of murine leukemia virus and the pathogenesis of immune complex glomerulonephritis of New Zealand mice. J Exp Med. 1974;140:1011-27.

17. Sekigawa I, Ogasawara H, Kaneko H, Hishikawa T, Hashimoto H. Retroviruses and autoimmunity. Intern Med. 2001;40:80-6.

18. Adelman MK, Marchalonis JJ. Endogenous retroviruses in systemic lupus erythematosus: candidate lupus viruses. Clin Immunol. 2002;102:107-16.

19. Ito H, Harada R, Uchida Y, Odashiro K, Uozumi K, Yasumoto Y, et al. Lupus nephritis with adult $\mathrm{T}$ cell leukemia. Nephron. 1990;55:325-8.

20. Fritsch-Stork RD, Leguit RJ, Derksen RH. Rapidly fatal HTLV1-associated T-cell leukemia/lymphoma in a patient with SLE. Nat Rev Rheumatol. 2009;5:283-7.

21. Miura T, Tanaka H, Makino Y, Okamoto K, Iida T, Komura K, et al. Human T cell leukemia virus type I-associated myelopathy in a patient with systemic lupus erythematosus. Intern Med. 1999;38:512-5.

22. Wakui H, Masai R, Okuyama S, Ohtani H, Komatsuda A, Toyoshima I, et al. Development of lupus nephritis in a patient with human T-cell lymphotropic virus type I-associated myelopathy. Am J Kidney Dis. 2005;46:e25-9.

23. Sugimoto T, Okamoto M, Koyama T, Takashima H, Saeki M, Kashiwagi A, Horie M. The occurrence of systemic lupus erythematosus in an asymptomatic carrier of human T-cell lymphotropic virus type I. Clin Rheumatol. 2007;26:1005-7.

24. Weening JJ, D'Agati VD, Schwartz MM, Seshan SV, Alpers CE, Appel GB, et al. The classification of glomerulonephritis in systemic lupus erythematosus revisited. J Am Soc Nephrol. 2004;15:241-50.

25. Brüggemann $M$, White $H$, Gaulard $P$, Garcia-Sanz R, Gameiro P, Oeschger $\mathrm{S}$, et al. Powerful strategy for polymerase chain reaction-based clonality assessment in T-cell malignancies Report of the BIOMED-2 Concerted Action BHM4 CT98-3936. Leukemia. 2007;21:215-21.

26. Shimamoto Y, Nomura S, Ishii K, Shimizu M, Ozaki Y, Ito T, et al. Adult T-cell leukemia after immunosuppressive therapy for systemic lupus erythematosus. Int J Hematol. 2009;89:128-9.

27. Park MH, D'Agati V, Appel GB, Pirani CL. Tubulointerstitial disease in lupus nephritis: relationship to immune deposits, interstitial inflammation, glomerular changes, renal function, and prognosis. Nephron. 1986;44:309-19. 